\title{
Hate Speeches and Disrespect for the Opposition Parties in Nigeria: Implications for Democratic Consolidation and National Development
}

\author{
Rufus Anthony (PH.D cand)*, Michael N Anyanwu \\ Department of Political Science, Niger Delta University, Nigeria
}

Copyright $(2019$ by authors, all rights reserved. Authors agree that this article remains permanently open access under the terms of the Creative Commons Attribution License 4.0 International License

\begin{abstract}
A major "display" of party politics especially in this democratic dispensation is characterized with the use of verbal arsenals (hate speeches) against the opposition party. Never in the history of Nigeria has this level of verbal disrespect been experienced. There is no gainsaying the negative effects of hate speeches heating up the polity and sowing seeds of disunity. This paper therefore examines the politics of hate speeches and disrespect for opposition parties and the implication for democratic consolidation and national development in Nigeria. It is therefore the opinion of this work that hate speeches and disrespect for the opposition parties are factors hindering the success of elections in recent times and consequently impeded democratic consolidation and national development/integration. This further threatens the continued existence of the Nigerian state. It is on the above premise this paper recommends a legal check on hate speeches to foster democratic consolidation and national integration. Content analysis was used both as an instrument of data collection and analysis.
\end{abstract}

Keywords Hate Speeches, Opposition Parties, Democratic Consolidation, National Development and Integration

\section{Introduction/Statement of Problem}

Nigeria's democracy is hinged on party politics. Unfortunately, the role of political parties in consolidating democracy and engendering national development in the country is greatly undermined by their modus operandi geared towards winning election contests by all means. The desperation by political parties in Nigeria to acquire and control political power has made them resort to all sorts of activities, legal and illegal, moral and immoral to ensure that each captures political power at all cost. This explains why the historical trajectory of the electoral process in the colonial and post-colonial Nigeria is characterized by violence (Adesote \& Abimbola, 2014), electoral fraud, maladministration and sharp practices (Ogoh, 2016) which often stimulates tension and unrest. In Nigeria's political history, particularly since the first elections held in the country under the 1922 Clifford Constitution, the Nigerian political terrain has experienced pockets of crises that could be traced to hate speech, among other anti-social behaviors (The Nigerian Observer, 2015).

In fact, Nigeria democracy and transition from one civilian administration to another, especially since the inception of the Fourth republic in 1999, has been characterized by gross disrespect for political opposition parties and vulgar utterances from political aspirants and opponents despite national and international Law legal frameworks both prohibiting such conduct. Electioneering contests, at some point, further degenerated and exacerbated into a string of hate campaigns leading to allegations and counter allegations among frontline political parties and their candidates. The campaigns of major political parties were characterized by verbal attacks and are bereft of developmental and innovative ideas (Baiyewu, 2015). Also, political gladiators go beyond stipulated and acceptable norms and practices in some of their actions and inactions (Odufowokan, 2015) which culminate into socio-economic tension and unrest that pose a serious threat to democratic consolidation and national development.

In the buildup to the 2015 general election, Rev. Father Mbaka urged his Adoration Ministry followers not to vote for President Goodluck Jonathan in the coming month's election, while Fayose took the front page of a national newspaper to suggest that All Progressives Congress, APC, presidential candidate, Muhammadu Buhari, would likely die in office if elected, reminding people that Murtala Muhammed, Sani Abacha and Umaru Yar'Adua, all former heads of state from the Northwest like Buhari, had 
died in office (ICIR, 2015). Some of these statements credited to politicians, religious leaders, and their supporters have become a real source of worry that, if left unchecked, is capable of plunging the country into serious crises (Malik, 2015). For instance, the Chairman, Governing Council of the National Human Rights Commission (NHRC), Prof. Chidi Odinkalu noted that the mayhem which trailed Kenyan elections in 2007 could be partly attributed to hate speech by some Kenyan politicians. $\mathrm{He}$, however, underscored the need to ensure that the Kenyan experience did not replicate itself in Nigeria (The Nigerian Observer, 2015).

The role of hate speech and disrespect for opposition parties in political unrest and tension has been established in Nigeria with the 2011 post-electoral violence in the country as the most notable example (Chedotum, Cheserek, Kiptui, and Arusei, 2013). Corroborating this, Akubor (2015) noted that the 2011 post-election violence in Nigeria shows that hate speech played a major role in inciting people against one another. Also, prior to the 2015 general elections, the country witnessed series of hate speeches by opposing political parties, especially between the All Progressives Congress (APC) and the People's Democratic Party (PDP) (Odunayo, 2016). With the alarming spate of hate speeches and disrespect for opposition parties in Nigeria, this paper seeks to examine their implication on democratic consolidation and national development in the country. The paper, therefore, is divided into five sections. The first section is the introduction; the second section focuses on conceptual clarification; the third section highlights evidence of hate speeches in Nigeria; the fourth part discusses national and international law legal frameworks prohibiting hate speeches while the fifth section focused on the implication of hate speeches on democratic consolidation and national development. The paper was concluded in the sixth section.

\section{Conceptual Definition}

\section{Meaning and Dimensions of Hate Speech}

Several attempts have been made to define the meaning of hate speech. The Committee of Ministers of the Council of Europe conceived hate speech as covering all forms of expressions which spread, incite, promote or justify racial hatred, xenophobia, anti-Semitism, or other forms of hatred based on intolerance. As a result, it generates stigmas, stereotypes, prejudices and discriminatory practices against those who are constructed as being different (ICIR, 2015). Hate speech to Kukah (2015) is any communication that denigrates a particular person or a group on the basis of race, color, ethnicity, gender, disability, sexual orientation, nationality, religion, or other characteristic; it can be in the form of any speech, gesture or conduct, writing, or display and usually marks incitement, violence or prejudice against an individual or a group. It is speech that employs discriminatory epithets to insult and stigmatize others on the basis of their race, ethnicity, gender, sexual orientation or other forms of group membership (Adibe, 2015).

In the Nigerian context, hate speech include acts of insulting people for their religion; abusing people for their ethnic or linguistic affiliation; expressing contempt against people because of their place of origin; abusing or desecrating symbols of cultural or religious practices; denigrating or ridiculing traditional or cultural institutions of other people, and deliberately spreading falsehood or rumors that demeans or maligns or otherwise ostracizes other people on the basis of religion and ethnicity, gender or place of origin (Umar, 2015).

From the foregoing definitions, it suffices to align with the thought of a political scientist and media commentator, Jideofor Adibe that hate speech is a catalyst for violence and that it is very doubtful if there would be hate-motivated violent attack anywhere without hate speech and the hatred that it purveys (ICIR, 2015).

\section{Democratic Consolidation}

Democratic consolidation as defined by Diamond is the process of achieving broad and deep legitimation such that all significant political actors believe that popular rule is better for their society than any other realistic alternative they can imagine. It also connects the act of reducing the probability of the breakdown of the system to the point where democracy can be said that it will persist (Muhammad, 2013). This implies a democracy that can last for the test of time. This can be assured if those values that made democracy worthwhile are fully institutionalized (Nwokeke and Jayum, 2011). To some scholars, democratic consolidation is viewed as regime maintenance and regarding the key political institutions as the only legitimate framework for political contestation and adherence to the democratic rules of the game. It manifest under enhanced economic development, developed democratic culture and stable party system (Muhammad, 2013).

\section{National Development}

The term national development refers to a sustainable growth and development of a nation to a more desirable one. National development is people oriented and its success is evaluated in terms of the impact it has had in improving the lot of the masses (Adekoya \& Ajilore, 2012). In this direction, Enahoro, posited that national development should be man oriented and not institution oriented, that is, individually in collectiveness and not individual (Onabajo \& M'Bayo, 2009).

Boutrous, B. Ghali, a former Secretary of United Nations Organization in May, 1994, issued a document which categorizes development into five dimensions which 
are peace, economy, environment, social studies and democracy. In the Nigerian context, these components are missing as democratic processes are absent and the government in power abuses the rule of law. Thus, the process does not create opportunities for opposition to strive and majority of those in power are there on the basis of what to get and the development of their various communities is not their priority (Omoyibo and Agbonzeke, 2010:284).

\section{Evidence of Hate Speeches in Nigeria}

Electioneering campaigns in Nigeria democratization process have been turned into a theatre of abhorrence utterances and disrespect for political oppositions. The Table 1 below shows some notable hate speeches stated by some Nigerian political and religious frontrunners.

Table 1. Hate speeches in Nigeria, 2010-2015

\begin{tabular}{|c|c|c|c|c|}
\hline $\mathrm{S} / \mathrm{N}$ & Year & Hate Speaker & Hate speech & Sources \\
\hline 1 & 2010 & $\begin{array}{l}\text { The former Governor of the old } \\
\text { Kaduna State, Alhaji Lawan } \\
\text { Kaita }\end{array}$ & $\begin{array}{l}\text { The North would make the country ungovernable if President } \\
\text { Goodluck Jonathan wins the } 2011 \text { polls... Anything short of a } \\
\text { Northern President is tantamount to stealing our presidency. }\end{array}$ & $\begin{array}{l}\text { Jason, } 2011 \text { (See } \\
\text { references) }\end{array}$ \\
\hline 2 & 2010 & $\begin{array}{l}\text { Shehu Sani, a Kaduna based } \\
\text { civil rights activist }\end{array}$ & $\begin{array}{l}\text { President Goodluck Jonathan should not contemplate } \\
\text { contesting the } 2011 \text { presidential election. Any attempt by him } \\
\text { to contest amounts to incitement and a recipe for political } \\
\text { instability }\end{array}$ & $\begin{array}{l}\text { www.nigerianbestf } \\
\text { orum.com./shehusan } \\
\text { i-warnsjonathan-aga } \\
\text { instcontesting }\end{array}$ \\
\hline 3 & 2010 & $\begin{array}{l}\text { National Coordinator of the } \\
\text { Coalition of Northern } \\
\text { Politicians, Dr. Junaidu } \\
\text { Mohammed }\end{array}$ & $\begin{array}{l}\text { It must be a Northerner or no Nigeria... If Goodluck Jonathan } \\
\text { wins the PDPes endorsement to contest the } 2011 \text { presidential } \\
\text { election, there would be violence. }\end{array}$ & $\begin{array}{l}\text { Interview with } \\
\text { Guardian } \\
\text { Newspaper, 2nd } \\
\text { November, 2010 }\end{array}$ \\
\hline 4 & 2011 & $\begin{array}{c}\text { Presidential Candidate of } \\
\text { Congress for Progressive } \\
\text { Change, General Muhammadu } \\
\text { Buhari }\end{array}$ & $\begin{array}{l}\text { God willing, by } 2015 \text {, something will happen. They either } \\
\text { conduct a free and fair election or they go a very disgraceful } \\
\text { way. If what happened in } 2011 \text { should again happen in } 2015 \text {, } \\
\text { by the grace of God, the dog and the baboon would all be } \\
\text { soaked in blood }\end{array}$ & $\begin{array}{l}\text { Reported by Lika } \\
\text { Binniyat in } \\
\text { Vanguard } \\
\text { Newspaper on May } \\
\text { 15th, } 2012 \\
\end{array}$ \\
\hline 5 & 2012 & $\begin{array}{l}\text { National Coordinator of the } \\
\text { Coalition of Northern } \\
\text { Politicians, Dr. Junaidu } \\
\text { Mohammed }\end{array}$ & $\begin{array}{l}\text { Unless efforts are made to ensure that the } 2015 \text { general } \\
\text { election are free and fair, it may turn out to be the last election } \\
\text { in the history of the nation }\end{array}$ & $\begin{array}{l}\text { Leadership March } \\
\quad 29,2012\end{array}$ \\
\hline 6 & 2012 & $\begin{array}{l}\text { Chinua Achebe, a foremost } \\
\text { Nigerian writer }\end{array}$ & $\begin{array}{l}\text { The Igbo culture being receptive to change, individualistic } \\
\text { and highly competitive gave the Igbo man an unquestionable } \\
\text { advantage... Unlike the Hausa/ Fulani, he was unhindered by } \\
\text { a wary religion and unlike the Yoruba, he was unhampered by } \\
\text { traditional hierarchies }\end{array}$ & $\begin{array}{l}\text { Achebe, Chinua } \\
\quad(2012: 74)\end{array}$ \\
\hline 7 & 2013 & $\begin{array}{l}\text { National Coordinator of the } \\
\text { Coalition of Northern } \\
\text { Politicians, Dr. Junaidu } \\
\text { Mohammed }\end{array}$ & $\begin{array}{l}\text { There will be bloodshed. Those who feel short-changed may } \\
\text { take the war path and the country may not be the same again }\end{array}$ & $\begin{array}{l}\text { Reported by Kemy } \\
\text { Oguns in Osun } \\
\text { Defender, 2nd } \\
\text { December, } 2013\end{array}$ \\
\hline 8 & 2013 & $\begin{array}{l}\text { Femi Fani-Kayode, a former } \\
\text { Aviation Minister }\end{array}$ & $\begin{array}{l}\text { The Igbos are collectively unlettered, uncouth, uncultured, } \\
\text { unrestrained and crude in all their ways... Money and the } \\
\text { acquisition of wealth is their sole objective and purpose in life }\end{array}$ & $\begin{array}{l}\text { Daily Post, August } \\
8,2013\end{array}$ \\
\hline 9 & 2013 & $\begin{array}{l}\text { The leader of the Niger Delta } \\
\text { Peoples Salvation Force } \\
\text { (NDPSF), Alhaji Mujahid } \\
\text { DokuboAsari }\end{array}$ & $\begin{array}{l}\text { There will be no peace, not only in the Niger Delta, but } \\
\text { everywhere if Good luck Jonathan is not president by } 2015 \text {, } \\
\text { except God takes his life, which we do not pray for }\end{array}$ & $\begin{array}{l}\text { Vanguard } \\
\text { Newspapers, May 5, } \\
2013\end{array}$ \\
\hline 10 & 2013 & $\begin{array}{l}\text { Chief Arthur Eze PDP } \\
\text { Chieftain }\end{array}$ & That short man called Ngig & $\begin{array}{c}\text { Premium Times, } \\
\text { November 13, } 2013\end{array}$ \\
\hline 11 & 2014 & $\begin{array}{l}\text { Publicity Secretary of All } \\
\text { Progressive Congress, Alhaji } \\
\text { Lai Mohammed }\end{array}$ & $\begin{array}{l}\text { If the } 2015 \text { elections are rigged, the party will not recognize } \\
\text { the outcome and will go ahead and form a parallel } \\
\text { government }\end{array}$ & $\begin{array}{l}\text { Leadership 21st } \\
\text { November, 2014; } \\
\text { Sahara Reporters } \\
\text { 22nd November, } \\
\quad 2014\end{array}$ \\
\hline 12 & 2014 & $\begin{array}{l}\text { Governor Shema Ibrahim of } \\
\text { Kastina State }\end{array}$ & $\begin{array}{l}\text { You should not be bordered with cockroaches of politics. } \\
\text { Cockroaches are only found in the toilet even at homes, If you } \\
\text { see cockroach in your house, Crush them }\end{array}$ & $\begin{array}{l}\text { Reported by } \\
\text { Premium Times on } \\
\text { 19th November, } \\
2014\end{array}$ \\
\hline 13 & 2014 & An Islamic cleric, Ima Sadiq & Muslims, vote for Buhari. It is a sin to support a non-Muslim & $\begin{array}{l}\text { Twitter handle, } \\
\text { Saturday, } 27 \text { th } \\
\text { December, } 2014\end{array}$ \\
\hline 14 & 2014 & Northern Elder Forum & $\begin{array}{l}\text { Those who vote for Jonathan and the PDP in } 2015 \text { will be } \\
\text { considered an enemy of the north }\end{array}$ & $\begin{array}{l}\text { Vanguard, } 15 \\
\text { October } 2014 .\end{array}$ \\
\hline
\end{tabular}




\begin{tabular}{|c|c|c|c|c|}
\hline 15 & 2014 & Asiwaju Bola Tinubu & $\begin{array}{l}\text { It is going to be rig and roast. We are prepared not to go to } \\
\text { court but drive them out }\end{array}$ & Tell, 7 July 2014. \\
\hline 16 & 2014 & $\begin{array}{l}\text { Former Governor of Akwa } \\
\text { Ibom State, Godswill Akpabio }\end{array}$ & $\begin{array}{l}\text { Those who want to take power through the back door will die. } \\
\text { They will die }\end{array}$ & $\begin{array}{l}\text { Punch Newspaper, } \\
17 \text { th July, } 2014\end{array}$ \\
\hline 17 & 2014 & $\begin{array}{l}\text { South East Self Determination } \\
\text { Coalition (SESD) }\end{array}$ & $\begin{array}{l}\text { We assure those cold blooded murderers that this time, their } \\
\text { blood thirsty campaign will not go un-replied }\end{array}$ & $\begin{array}{l}\text { Reported by Clifford } \\
\text { Ndujihe in Vanguard } \\
\text { Newspaper, 5th } \\
\text { December, } 2014\end{array}$ \\
\hline 18 & 2014 & Alhaji Mujahid Dokubo-Asari & $\begin{array}{l}2015 \text { is more than do-or-die. You are a man and I am a man, } \\
\text { we are going to meet at the battlefield }\end{array}$ & $\begin{array}{l}\text { News Express 3rd } \\
\text { May, } 2014\end{array}$ \\
\hline 19 & 2014 & Alhaji Mujahid Dokubo-Asari & $\begin{array}{l}\text { If they contest (Northerners) they are wasting their time. He } \\
\text { who pays the piper will dictate the tune. We own them. We } \\
\text { are feeding them. They are parasites. A beggar has no } \\
\text { choice... They are beggars and parasites }\end{array}$ & $\begin{array}{l}\text { http://www.vanguar } \\
\text { dngr.com/2014/12/ } \\
\text { north-ungratefulpara } \\
\text { sites-asaridokubo). }\end{array}$ \\
\hline 20 & 2014 & $\begin{array}{l}\text { Rivers States Governor, Rotimi } \\
\text { Amechi }\end{array}$ & $\begin{array}{l}\text { The challenge of the Nigerian military is not funding but } \\
\text { corruption. Now they want to kill some } 50 \text { officers for their } \\
\text { own failure to equip them properly to fight terrorism. The } \\
\text { soldiers have the right to protest for the federal government's } \\
\text { failure to fully equip them }\end{array}$ & $\begin{array}{l}\text { This day and } \\
\text { Nations, Tuesday, } 9 \\
\text { th December, } 2014\end{array}$ \\
\hline 21 & 2015 & $\begin{array}{l}\text { Wife of former President, } \\
\text { Patience Jonathan }\end{array}$ & $\begin{array}{l}\text { Wetin him dey find again? Him dey drag with him pikin mate, } \\
\text { old man wey no get brain, him brain don die pata pata - What } \\
\text { is Buhari looking for? Old man that does not know his age. } \\
\text { Your brain is dead. }\end{array}$ & $\begin{array}{l}\text { At a PDP rally in } \\
\text { Kogi state, Reported } \\
\text { by The Express } \\
\text { New, } 4 \text { March, } 2014\end{array}$ \\
\hline 22 & 2015 & $\begin{array}{l}\text { Wife of former President, } \\
\text { Patience Jonathan }\end{array}$ & $\begin{array}{l}\text { Our people do not give birth to uncountable children. Our } \\
\text { men don't give birth to children that they dump in streets. We } \\
\text { are not like people from that part of the country (apparently } \\
\text { the northern Nigeria) }\end{array}$ & $\begin{array}{l}\text { Presidential } \\
\text { campaign in } \\
\text { Calabar, The Nation, } \\
\text { March } 10,2015\end{array}$ \\
\hline 23 & 2015 & $\begin{array}{l}\text { Wife of former President, } \\
\text { Patience Jonathan }\end{array}$ & $\begin{array}{l}\text { Anybody that come and tell you changes, stone that person... } \\
\text { What you did not do in } 1985 \text {, is it now that old age has caught } \\
\text { up with you that you want to come and change...Y You cannot } \\
\text { change rather you will turn back to a baby }\end{array}$ & $\begin{array}{l}\text { The Complete } \\
\text { Works of Patience } \\
\text { Jonathan, The } \\
\text { Nation on Sunday, } \\
\text { 15th March }\end{array}$ \\
\hline 24 & 2015 & $\begin{array}{l}\text { The Governor of Ekiti State, } \\
\text { Peter Ayodele Fayose }\end{array}$ & $\begin{array}{l}\text { Buhari would likely die in office if elected, recall that Murtala } \\
\text { Muhammed, Sani Abacha and Umaru Yar'Adua, all former } \\
\text { heads of state from the North West like Buhari, had died in } \\
\text { office }\end{array}$ & $\begin{array}{l}\text { January } 19,2015 \text {, } \\
\text { ThisDay and other } \\
\text { national dailies }\end{array}$ \\
\hline 25 & 2015 & Oba Akiolu of Lagos & $\begin{array}{l}\text { On Saturday, if anyone of you, I swear in the name of God, } \\
\text { goes against my wish that Ambode will be the next governor } \\
\text { of Lagos state, the person is going to die inside this } \\
\text { water...For the Igbos and others in Lagos, they should go } \\
\text { where the Oba of Lagos heads to... }\end{array}$ & $\begin{array}{l}\text { ThisDay } \\
\text { Newspaper, 4th } \\
\text { April } 2015\end{array}$ \\
\hline 26 & 2015 & $\begin{array}{l}\text { Dr. Abraham Ariyo, U.S based } \\
\text { Nigerian Doctor }\end{array}$ & $\begin{array}{l}\text { You see how they (Igbos) are being slaughtered in South } \\
\text { Africa. That is what is going to happen to them in Lagos... } \\
\text { When are they (Igbos) going to be slaughtered in Abuja? We } \\
\text { will continue to bus them to Onitsha }\end{array}$ & $\begin{array}{l}\text { Facebook page of } \\
\text { Dr. Ariyo, Reported } \\
\text { in Quick News } \\
\text { Africa, April 20, } \\
2015 .\end{array}$ \\
\hline 27 & 2015 & $\begin{array}{l}\text { Wife of former President, } \\
\text { Patience Jonathan }\end{array}$ & $\begin{array}{l}\text { The PDP is a party that talks less and does more, unlike the } \\
\text { APC that tells new lies every week. When you catch them } \\
\text { today, they will tell another lie tomorrow. We (PDP) do not } \\
\text { tell you about change because we are not bus conductors that } \\
\text { ask for change. }\end{array}$ & $\begin{array}{l}\text { https://www.naij.co } \\
\mathrm{m} / 663921-2015 \text { inre } \\
\text { view-events-shook-n } \\
\text { igerians-2015.html }\end{array}$ \\
\hline 28 & 2015 & $\begin{array}{l}\text { Wife of former President, } \\
\text { Patience Jonathan }\end{array}$ & $\begin{array}{l}\text { Anybody that come and tell you change, stone that person. } \\
\text { Anybody that come and tell you he will change, stone that } \\
\text { person. }\end{array}$ & $\begin{array}{l}\text { https://www.naij.co } \\
\mathrm{m} / 663921-2015 \text { inre } \\
\text { view-events-shook-n } \\
\text { igerians-2015.html }\end{array}$ \\
\hline 29 & 2015 & $\begin{array}{l}\text { Former River State governor, } \\
\text { Rotimi Amaechi }\end{array}$ & $\begin{array}{l}\text { the All Progressives Congress party, (The APC) will form a } \\
\text { parallel government if the Feb. 14th and 28th elections are } \\
\text { rigged }\end{array}$ & $\begin{array}{l}\text { http://www.peoplesd } \\
\text { ailyng.com/2015-ele } \\
\text { ctions-and-negative- } \\
\text { effects-of-hate-speec } \\
\text { hes/ }\end{array}$ \\
\hline 30 & & $\begin{array}{l}\text { Director of Media and } \\
\text { Publicity, PDP's presidential } \\
\text { campaign organization, Chief } \\
\text { Femi Fani-Kayode }\end{array}$ & $\begin{array}{l}\text { We (PDP) know that they (APC) may have a few challenges } \\
\text { with the English language; so, if they like they can even } \\
\text { conduct the debate in vernacular: we would be prepared to } \\
\text { pay for a translator or an interpreter just so that they could } \\
\text { understand the proceedings }\end{array}$ & $\begin{array}{l}\text { http://www.peoplesd } \\
\text { ailyng.com/2015-ele } \\
\text { ctions-and-negative- } \\
\text { effects-of-hate-speec } \\
\text { hes/ }\end{array}$ \\
\hline
\end{tabular}




\section{National and International Law Legal Frameworks Prohibiting Hate Speeches}

Conditions abound under which freedom of expression could be restricted by law, especially when it injures the reputations of others. Apart from the international legal framework which the International Covenant on Civil and Political Rights that discourages hate speech is prominent, there are laws in Nigeria especially the Electoral Act that defines, prohibits and punishes hate speech during election campaign periods in the country (Okakwu, 2015). Sections of Nigeria's 2010 Electoral Act that frown upon hate speech and inciting comments as enumerated by the International Center for Investigative Reporting (ICIR) are as follows:

\subsection{Section 95 (1)}

No political campaign, slogan shall be tainted with abusive language directly or indirectly, likely to injure religious, ethnic, tribal or sectional feeling (ICIR, 2015).

\subsection{Subsection 2}

Abusive, intemperate, slanderous or base language or insinuations or innuendos designed or likely to provoke violent reactions or emotions shall not be employed or used in political campaigns (ICIR, 2015).

\subsection{Subsection 3}

Places designated for religious worship, police stations, and public places shall not be used for political campaigns, rallies, and processions or to promote, propagate or attack properties, candidates or their programs or ideologies (ICIR, 2015).

\subsection{Section 102}

Any candidate or person or association who engages in campaigning or broadcasting based on religious, tribal or sectional reason for the purpose of promoting, opposing a particular political party or the election of a particular candidate is guilty of an offense. According to the Act, the punishment for this offense is a fine of not more than N1,000, 000 or imprisonment for 12 months or both (ICIR, 2015).

\section{Implication of Hate Speeches on Democratic Consolidation and National Development}

Scholars have argued that political campaigns in Nigeria have deviated from the original norm. It is a do-or-die affair in the country, because the accepted norm is that incumbents do not lose elections (Nigerian Insight, 2015). Instead of the political actors to sensitize the political community in relation to making the community considers them as potentials and better representatives of the people, they engage more in hate speeches (Akubor, 2015) and disdain for opposition parties. Electioneering campaigns are odiously bereft of serious ideas and are acidic, full of character assassination, frivolities and vitriolic personal abuses (Nigerian Insight, 2015). It was because of the exacerbating ugly situation that the world according to the chairman of the National Human Rights Commission, Chidi Odinkalu believed that Nigeria was going to eat itself up in the 2015 elections (Premium Times, 2015). Hate Speeches and disrespect for opposition party pose grave consequence on democratic consolidation and national development in Nigeria in the following ways:

\subsection{Crises and Breakdown of Law and Order}

Hate speech is the foremost driver of violent conflicts (CITAD, 2016) since words have power and can influence others to act (New Internationalist Magazine, 2012). In most countries where the people and their political class do not respect opposition parties or curtail the use of hate speeches in campaigns and political activities, the end has always been disastrous (Akubor, 2015); because most often, those seeking certain political powers become reckless in the use of language that (knowingly or unknowingly), they denigrate a particular person or a group on the basis of race, color, ethnicity, gender, disability, sexual orientation, nationality, religion, or other characteristics. This was the case in Kenya and Rwanda (Akubor, 2015) and Cote d'Ivoire. In the Kenyan scenario, it has been established that the disputed 2007 Presidential election in the country resulted in an outbreak of post-election violence that left over 1,000 people dead and over 600,000 people displaced. The post-election inquiries concluded that hate speech and incitement to violence was widespread on the campaign trail and in the mainstream media, exploiting tensions between ethnic communities (IHRB, 2013). Later on, a few politicians were arrested for engaging in hate speech and inciting violence (CRHS, 2013). Also, the 1994 Rwandan genocide followed the downing of an airplane carrying the Rwandan President, Juvénal Habyarimana and the President of Burundi, Cyprien Ntaryamira took place in an already heated atmosphere (Surminski and Schreiber 2007).

In the aftermath of a lost election, the incumbent president of Cote d'Ivoire, Laurent Gbagbo refused to accept his defeat. Along with his wife, Simone Gbagbo, he organized parallel State's structures, attempted to censor the media and reinforced his hate speech against ethnicities living in the North of the country which heightened the level of attack and destruction in the land. At the end of the day, over 3000 deaths were recorded, while thousands of 
hundreds of refugees from the country were scattered all over West Africa. Laurent Gbagbo's wife was jailed for 20 years for the inflammatory statements she made in the post-violence of the 2011 election in Ivory Coast (Akubor, 2015).

A careful analysis of the Ahmed Lemu's Panel Report on the 2011 post-election violence in Nigeria shows that hate speech played a major role in inciting people against one another. As a result of this, according to the report, more than 1000 persons were killed across the country with Kaduna State having the highest casualties of about 847 during the post-election violence of 2011 (Akubor, 2015). During the countdown to the presidential election held on 28 March 2015, there was a lot of apprehension about the elections turning violent because of previous experiences as some politicians saw the elections as a do-or-die affair, fighting dirty with acerbic words, half-truths and outright lies in their electioneering campaigns (Ibraheem, Ogwezzy $\&$ Tejumaiye, 2015).

Hate speeches and disrespect for opposition party if continues unabated in the country can further instigate and sustain ethno-religious and political crises and violence. Democracy and Development are put in abeyance in a country with anarchic situation. That is, crises caused hate speeches and disrespect for opposition party might bring a democratic process to an abrupt end and pose a serious setback to national development. For instance, the Nigeria/Biafra Civil War wound back the country's development as it caused the destruction of lives and property and the stoppage of economic activities. Countries experiencing political crises are usually politically retarded, economically backward and technologically lagging. Countries like Cambodia, Sudan, and other war-ravaged countries are good examples.

\subsection{Loss of Human Lives and Destruction of Property}

When hate speeches and disregard for opposition parties plunge a country into serious crises, colossal loss of human lives and destruction of invaluable property are inevitable. This is noticeable in the various cases of electoral violence which has claimed several lives, displacement of innocent people and wanton destruction of property (Adesote \& Abimbola, 2014). For instance, in December 2003, the U.N. International Criminal Tribunal for Rwanda jailed several media executives on grounds of incitement and conspiracy to commit genocide and crimes against humanity. Specifically, the tribunal pointed out how the media executives caused the deaths of thousands of innocent civilians without firearms, machete or any physical weapons in actions through articles that created the psychological disposition favorable to genocide (CITAD, 2016). The implication of this genocide is that huge human capital necessary for national development is wasted and also the strength of the electorate in a democratic process is whittled down. Hate speech is commonly connected to hate-based acts of murder, battery, rape, assault, and property theft or damage (Heinze, 2014).

\subsection{Political Apathy}

Some desperate politicians resort to threats and hate statements when they fear that they might lose elections. This could raise tensions and sense of insecurity in the Nigerian political system that can produce negative political behaviors among the citizens including lack of interest towards political activities since public confidence in the country's overall political process will likely be eroded. Feeling threatened by the tensed political system, citizens could refuse to join a political party, vote in an election or participate in voter's registration exercise which is an essential aspect and pre-condition for voting in an election and essential ingredients of democratic consolidation and national development.

Perceived threats discourage the electorate or voters from exercising their franchise and thereby creates the unacceptable situation of 'low turnout' during general elections. For instance, the Osun State Governor, Rauf Aregbesola was reported to have called on the All Progressives Congress (APC) supporters to attack security agents with charms and amulets during the August 9, 2014, governorship election in the state (Wahab, 2014:48). The alleged calls for the use of amulets and perceived possible outbreak of violence in the voting arena could possibly scare away large credible and patriotic number of voters from active participation in the electoral process. Okoro (2012) noted that in the governorship elections conducted in five states namely Kogi, Cross River, Adamawa, Bayelsa and Sokoto states there were reports of low turnout of voters in most cases which was partly as a result of fear of the already tensed political environment.

\subsection{Threatens Political Tolerance and National Cohesion}

Detribalised leaders and politicians who will strive to achieve national integration, cohesion, and unity knowing that unity is the bedrock of national growth and democratic consolidation have continued to elude the Nigerian state. Hate speech and disrespect for opposition promotes division and intolerance among Nigerians. They cause psychological harm that threatens national unity which is counter-productive to democratic consolidation and national development. Several parts of Nigeria are today convulsed in political intolerance which manifests in inter and intra-ethnic/religious conflicts leading to loss of lives as well as the destruction of private and public properties. Political disunion and bigotry can cause retardation in the growth of political consciousness, ideas, innovation, and creativity among people necessary for national development and democratic consolidation due to the fear of misconception of such ideas by other ethnic, religious 
and political groups.

\section{Conclusions}

Certainly, the problem of hate speech and disrespect for the opposition party is more of a universal phenomenon but has become observable widespread in Nigeria politics. Rather than being a medium for conveying messages to the electorate on the ideas the candidate wants to share with the voters, electioneering campaigns are perceived as an opportunity to indulge in defamation, condemnation and outright disrespect of political oppositions and the ethnic nationalities they belong. The national and international law legal frameworks prohibiting hate speeches; still, this violence-inciting act has continued to permeate every nook and cranny of the country unabated as offenders commit the crime with utmost impunity. None of those responsible for election hate speeches and violence in Nigeria in the past have been held to account.

In spite the decisive and timely steps that preceded the 2015 elections taken by some non-governmental organizations (NGOs) to organize several meetings and debates geared towards finding ways of putting an end to inciting comments and hate speeches, malicious overt verbal attacks on or the pelting of some party candidates in many parts of the country by a mob of youth hired by the oppositions were much observable still during the 2015 electioneering campaigns. Therefore, more need to be done to curb the proliferation of hate speech and disrespect for party opposition in Nigeria. The Nigerian government needs to take it seriously to enforce the national and international laws against hate speeches and punish appropriately those who commit the offense irrespective of social, political and religious status. The Media and Civil Society Organization should also be more committed to this course by ensuring that offenders are held to account and Nigerians sensitized in the direction that whereas politics may be perceived as a dirty game, it can only be controlled by rational actors, and that positive change is only feasible in Nigeria if they can be open-minded and embrace some inconvenient truths about political behavior. Rather than perceived enemy, leaders and members of political parties should perceive political opponents as partners in progress for democratic consolidation and national development.

\section{REFERENCES}

[1] Adekoya, H. O. \& Ajilore, K. (2012). Empowering National Development in Nigeria Through Appropriate National Communication Policy. Kuwait Chapter of Arabian Journal of Business and Management Review Vol. 2, No.3
[2] Adesote, A.S. \& Abimbola, J.O. (2014). Electoral Violence and the Survival of Democracy in Nigeria's Fourth Republic: A Historical Perspective. Canadian Social Science Vol. 10, No. 3

[3] Adibe, J (2012), Ethnicity, hate speech and nation-building, retrieved from http//www.elombah.com/index.php/article/ jideofor -adibe/12345/ethnicity-hate-speech-and nation-building, on 6/06/2015

[4] Akubor, E.O. (2015). Campaigns and Electioneering: Reflecting on the 2015 General Elections in Nigeria. http://www.inecnigeria.org/wp-content/uploads/2015/07/C onference-Paper-by-Emmanuel-Osewe-Akubor.pdf

[5] Baiyewu, L. (2015). Presidential election: Jonathan, Buhari's verbal warfare. Punch, January, 18

[6] Centre for Information Technology and Development (CITAD) (2016). CITAD'S Hate Speech Monitoring Project

in Nigeria.http:/www.citad.org/2016/08/05/citads-hate-speec h-monitoring-project-in-nigeria/

[7] Chedotum K, Cheserek G J, Kiptui M \&Arusei E J (2013). Causes and Effects Of Postelection Violence On Agricultural Production In Kesses Division, Uasin Gishu County, Kenya. Journal of Emerging Trends in Economics and Management Sciences (JETEMS), 4(1): 62-70.

[8] Ezeibe, C. C. (2014). Hate Speech and Electoral Violence in

Nigeria.http://www.inecnigeria.org/wp-content/uploads/20 15/07/Conference-Paper-by-Christian-Ezeibe.pdf

[9] Heinze, E. (2014). Nineteen Arguments for Hate Speech Bans - $\quad$ And Against Them.http://freespeechdebate.com/discuss/nineteen-argum ents-for-hate-speech-bans-and-against-them/

[10] Ibraheem, I., Ogwezzy, A. \& Tejumaiye, N. (2015). Beyond Influence: Media and the 2015 Presidential Election, Unpublished Paper.

[11] Institute for Human Rights and Business (2013). Corporate Responses to Hate Speech in the 2013 Kenya Presidential Elections $\quad$ Case Study: Safaricom https:/www.ihrb.org/pdf/DD-Safaricom-Case-Study.pdf

[12] International Center for Investigative Reporting (2015). When Hate Speech Crosses the Borderline of Freedom of Expression.

http://icirnigeria.org/when-hate-speech-crosses-the-borderl ine-of-freedom-of-expression/

[13] Kukah H (2015), Hate Speech Social Media And The 2015 Election; Hate Speech; Social Media And The 2015 Election ...pointblanknews.com/pbn/.../hate-speech-socialmedia-2015-election/

[14] Malik, S. (2015). When Hate Speech Crosses The Borderline Of Freedom Of Expression.http://icirnigeria.org/when-hate-speech-crosses -the-borderline-of-freedom-of-expression/

[15] Muhammad A. K. (2013). The Challenges of Democratic Consolidation in Nigeria's Fourth Republic. European Scientific Journal Vol.9, No.8

[16] New Internationalist Magazine (2012). Argument - Should hate speech be a crime?https://newint.org/sections/argumen 
t/2012/12/01/is-hate-speech-crime-argument/

[17] Nigerian Insight (2015). Moving Beyond the 2015 General Elections.http://nigerianinsight.com/moving-beyond-the-2 015-general-elections/

[18] Nwokeke P. O. \& Jayum A. J. (2011). The Electoral Process and Democratic Consolidation in Nigeria. Journal of Politics and Law. Vol. 4, No. 2

[19] Odufowokan, D. (2015). 2015 Campaigns: The issues, excesses, violations. The Nation, March, 29.

[20] Odunayo, A. (2016). 2015InReview: 16 Events That Shook Nigeria

2015.https://www.naij.com/663921-2015inreview-events-s hook-nigerians-2015.html

[21] Ogoh, A. O (2016). Elections and Democratic Consolidation in Nigeria: the Role of the International Community in the 2015 General Elections. Social Science and Law Journal of Policy Review and Development Strategies Vol. 5, No. 1

[22] Okakwu, E. (2015). 2015 Elections and Negative Effects of Hate
Speeches.http://www.peoplesdailyng.com/2015-elections-a nd-negative-effects-of-hate-speeches/

[23] Omoyibo, Kingsley, U. \& Agbonzeke, L. (2010) Obasanjo's Leadership and National Development (1999-2007): A Critical Appraisal, in Terhemba, W. and Talla, N.S. (eds). Governance and Economic Development in the Fourth Republic. Nigeria State: Aboki publishers, P. 284

[24] People's Daily (2015). 2015 elections and negative effects of hate speeches.http://www.peoplesdailyng.com/2015-elections-a nd-negative-effects-of-hate-speeches/

[25] Premium Times (2015). 58 Nigerians killed in 2015 pre-election violence so far - Rights Commission. http://www.premiumtimesng.com/news/headlines/17680258-nigerians-killed-2015-pre-election-violence-far-rights-c ommission.html

[26] The Nigerian Observer (2015). Checking Hate Speech among Nigerian Politicians.http://nigerianobservernews.com/2015/02/chec king-hate-speech-among-nigerian-politicians/\#.WPY4MYj yu00 